\title{
MANFAAT ES KRIM HERBAL TERHADAP PASIEN ANAK-ANAK PASCA OPERASI TONSILITIS DI RSU BHAKTI RAHAYU DENPASAR STUDI KASUS
}

\author{
Ni Komang Ayu Srinadi ${ }^{1}$, Anak Agung Putu Agung Mediastari ${ }^{2}$, Putu Lakustini \\ Cahyaningrum $^{3}$ \\ Prodi Kesehatan Ayurweda Fakultas Kesehatan Universitas Hindu Indonesia \\ ${ }^{1}$ ayusrinadirsbr@gmail.com ${ }^{*}{ }^{2} \mathrm{a}^{*}$ Coresponding author
}

\begin{abstract}
Abstrak
Es krim herbal merupakan produk es krim yang mengandung bahan herbal seperti daun kelor, mengkudu, rossela dan kayu manis. Penelitian ini bertujuan untuk mengetahui, mendeskripsikan dan mengaplikasikan bahwa pemberian es krim herbal terhadap pasien anak-anak pasca operasi tonsilitis menjadikan daya tarik serta meningkatkan minat anak-anak yang semuala terkendala mengkonsumsi loloh atau jamu. Penelitian ini menggunakan metode purposive sampling dengan jenis penelitian kualitatif. Dalam penelitian ini menggunakan teori etnomedicine dan teori fungsional struktural serta menggunakan pendekatan Ayurweda. Data dalam penelitian ini diperoleh melalui observasi, wawancara serta dokumentasi. Berdasarkan hasil penelitian, Pemberian es krim herbal sebagai makanan terhadap pasien anak-anak pasca operasi tonsillitis di RSU Bhakti Rahayu Denpasar karena es krim herbal mampu menambah nutrisi dan mempercepat penyembuhan karena beberapa tanaman yang digunakan tersebut mengandung unsur tanaman obat, vitamin dan mineral, setiap herbal per 100 gramnya mengandung vitamin C sebesar 0,009\%, protein sebesar 1,37\%, Karbohidrat sebesar 31,84\% dan gula sebesar $28,35 \%$. Tata cara pengolahan es krim herbal meliputi penghitungan adonan, persiapan adonan, pencampuran, pembekuan, dan pengemasan. 1 cup atau per 100 gram es krim herbal mengandung kalori sebanyak $388 \mathrm{kkal}$. Implikasi es krim herbal bagi penderita pasca operasi tonsilitis yaitu: mengurangi keluhan nyeri pada pangkal tenggorokan, mual, rasa perih, dan mempermudah proses makan dan minum pasien pasca operasi tonsilitis serta menambah nutrisi dan mempercepat pembekuan darah di area luka bekas pasca operasi tonsillitis sehingga mengurangi pendarahan.
\end{abstract}

Kata Kunci: Es Krim Herbal, Manfaat, Pasien Anak-Anak.

\begin{abstract}
Herbal ice cream is a ice cream product that contains herbal ingredients such as Moringa leaves, noni, rossela and cinnamon. This study aims to determine, describe and apply that giving herbal ice cream to pediatric patients after tonsillitis surgery attracts children's interest as well as to increase the interest of children who are all constrained by consuming loloh or herbal medicine. This research uses purposive sampling method with qualitative research type. This study uses ethnomedicine theory and structural functional theory and uses an Ayurvedic approach. The data in this study were obtained througobservation, interviews and documentation. Based on the results of the study, Giving herbal ice cream as food to pediatric patients after tonsillitis surgery at Bhakti Rahayu Hospital Denpasar because herbal ice cream can add nutrition and accelerate healing because some of the plants used contain elements of medicinal plants, vitamins and minerals, Each herb per 100 grams contains vitamin C by $0.009 \%$, protein by $1.37 \%$, carbohydrates by $31.84 \%$ and sugar by $28.35 \%$. Procedures for processing herbal ice cream include dough counting, dough preparation, mixing, freezing, and packaging. 1 cup or per 100 grams of herbal ice cream contains 388 kcal calories. The implications of herbal ice cream for sufferers after tonsillitis surgery are: reducing complaints of pain in the larynx, nausea, stinging, and simplifying the process of eating and drinking for patients after tonsillitis surgery as well as adding nutrition and accelerating blood clotting in the wound area after tonsillitis surgery so that reduce bleeding.
\end{abstract}

Keywords: Herbal Ice Cream, Benefits, Pediatric Patients. 


\section{Pendahuluan}

Penyakit infeksi merupakan penyakit yang mengancam seluruh umat manusia di muka bumi salah satunya yaitu tonsilitis. Tonsilitis adalah radang tonsil yang dapat mengenai semua umur tetapi utamanya terjadi pada anak-anak. Tonsilitis dapat disebabkan oleh infeksi bakteri atau virus, penyakit ini terjadi disebabkan peradangan pada tonsil karena kegagalan atau ketidaksesuaian pemberian antibiotik pada penderita tonsilitis akut (Ramadhan et al., 2017: 2).

Berdasarkan data dari Departemen Kesehatan Republik Indonesia, angka kejadian penyakit tonsilitis di Indonesia sekitar 23\%, berdasarkan data dari epidemologi penyakit THT di tujuh provinsi di Indonesia pada bulan September 2012, prevelensi tonsilitis kronik tertinggi setelah nesofaringitis akut, yaitu sebesar $3,8 \%$, ada beberapa faktor resiko yang dapat mempengaruhi terjadinya tonsillitis seperti mengkonsumsi goreng-gorengan kebiasaan minum-minuman dingin, dan hyegine mulut. Berdasarkan penelitian sebelumnya bahwa anakanak yang suka mengkonsumsi makanan dingin cenderung lebih banyak terkena penyakit tonsillitis, tetapi dalam proses penyembuhan pasca operasi tonsilitis biasanya mengunakan media es krim untuk mengurangi rasa nyeri pada bagian tenggorokan dan mengurangi rasa mual pada perut (Farokah et al., 2007: 87-91).

Es krim sangat diminati oleh anak-anak karena cita rasanya yang sesuai dengan selera anak, mudah di konsumsi dan bertekstur lembut serta kaya akan nutrisi. Es krim merupakan salah satu produk olahan susu bersifat semi padat, es krim dibuat melalui proses pembekuan dan agitasi dengan prinsip membentuk rongga udara pada campuran bahan es krim (Ice Cream Mix) sehingga dihasilkan pengembangan volume es krim, komposisi gizi per 100 gram es krim yang menonjol adalah energi $207 \mathrm{kkal}$, protein 4 gram dan lemak 12,5 gram (Astawan, 2008: 208).

Pengobatan pasca operasi tonsillitis di kota Denpasar khususnya di RSU Bhakti Rahayu memiliki keunikan dalam pengobatannya. Selama ini pasca operasi tonsilitis anak-anak di RSU Bhakti Rahayu Denpasar diberikan es krim yang dibeli di pasaran. Es krim yang dibeli di pasaran tersebut ada beberapa produk yang mengandung zat pewarna dan pencita rasa buatan sehingga memiliki dampak yang kurang baik bagi kesehatan, sehingga diperlukan inovasi untuk menciptakan es krim yang menggunakan bahan alami yang memiliki cita rasa yang khas dan memiliki kandungan nutrisi yang tinggi.
Salah satunya dengan mengunakan media es krim yang merupakan minuman dingin akan tetapi dalam penelitian ini menggunakan bahan herbal yang aman bagi kesehatan, sehingga memungkinkan untuk menunjang proses penyembuhan pasca operasi.

Pasien anak pasca menjalani operasi tonsilektomi membuat tenggorokan mengalami nyeri sehingga menyulitkan untuk menelan makanan atau minuman. Untuk itu dibutuhkan makanan yang bertekstur lembut dan mudah untuk ditelan. Produk herbal sudah banyak digunakan oleh masyarakat dari zaman dahulu untuk proses penyembuhan dan semakin marak penggunaannya di masyarakat saat ini karena harganya yang murah dan berkhasiat bagi kesehatan. Seiring perkembangan zaman teknologi pengolahan herbal semakin canggih, tidak ketinggalan dalam hal pengolahan es krim.

Es krim herbal merupakan produk herbal yang diformulasikan untuk penderita amandel atau tonsilitis karena selain teksturnya yang lembut juga memiliki kandungan nutrisi yang bermanfaat bagi penderita pasca operasi tonsilitis. Untuk meningkatkan nilai gizi es krim, maka ditambahkan dengan bahan daun kelor, mengkudu, rossela dan cinnamon atau kayu manis sebagai salah satu alternatif bahan campuran dalam pembuatan es krim. Pengolahan es krim dengan pemanfaatan bahan herbal daun kelor, mengkudu, rossela dan cinnamon atau kayu manis sebagai bahan campuran susu merupakan salah satu inovasi dalam pengolahan dan peningkatan nilai gizi pangan.

Berdasarkan latar belakang tentang kandungan dan manfaat tambahan bahan herbal dalam produk es krim ini diharapkan mampu memberikan cita rasa yang enak dan menyehatkan bagi tubuh karena ada tambahan dari bahan herbal tersebut. Hal ini mampu memberikan manfaat terhadap penyembuhan pasien dan meningkatkan daya tahan tubuh serta menambah nutrisi gizi anak-anak pasca operasi tonsilitis di RSU Bhakti Rahayu Denpasar. Maka dalam penelitian ini akan dilakukan penelitian tentang "Manfaat Es Krim Herbal Terhadap Pasien Anak-Anak Pasca Operasi Tonsilitis Di RSU Bhakti Rahayu Denpasar".

\section{Metode Penelitian}

Penelitian ini mengunakan pendekatan Ayurweda, Dalam Ayurweda dikenal dengan swasthya yaitu sehat secara jasmani dan bahagia serta diterima dalam kehidupan masyarakat, tidak terkucilkan terutama berkecukupan dari segi ekonomi. Sehat dalam Ayurweda adalah 
apabila semua sistem dan cairan tubuh berada dalam keadaan yang seimbang serta dapat berfungsi atau bekerja dengan baik (Nala, 2001:71).

Ayurweda dalam mengobati suatu penyakit mempergunakan beberapa pendekatan, salah satunya adalah ausadha. Dalam bahasa Sanskerta ausadha merupakan tumbuhan yang dapat dipergunakan sebagai bahan ramuan obat, bagian tumbuhan yang paling sering dipergunakan adalah akar (Mula), rimpang (Kandha), tunas (Vaya), batang (Valkala), kulit batang, daun (Palasa), bunga (Puspa), buah (Phala), biji (Bija), duri (Kikasa), cairan, getah, minyak dan lainya. Ayurweda juga membagi tanaman yang ada di bumi ini atas empat golongan yaitu: (1) Vanaspati tanaman yang menghasilkan buah. (2) Vanaspatya tanaman yang menghasilkan bunga dan buah. (3) Virudh tanaman yang batangnya menjalar. (4) Osadhi tanaman yang setelah berbuah, pohonya mengering dan mati (Nala, 2001:159-160).

Ayurweda mempunyai berbagai pendekatan untuk mengobati suatu penyakit, salah satunya adalah dengan mempergunakan bermacam-macam ramuan obat dalam berbagai bentuk produk, pengobatannya dapat berupa ramuan dari bahan tumbuhan yang digunakan dengan cara diminum, dioleskan, dihirup, disemprotkan dan sebagainya (Nala, 2001: 1-33).

Data dalam penelitian ini terdiri atas data kualitatif, terdiri dari data primer dan data sekunder. Data primer yang digunakan diperoleh dari lapangan dengan cara pemberian es krim herbal kepada pasien anak-anak pasca operasi tonsilitis serta mengamati atau mewawancarai pasien pasca operasi tonsilitis, tim ahli gizi dan dokter spesialis THT. sedangkan data sekunder bersumber terdiri dari data pasien, hasil lab hingga dokumen-dokumen medis dari instansi kesehatan. Data yang diambil dengan teknik purposive sampling dan diperoleh dengan metode studi kepustakaan, observasi dan wawancara wawancara mendalam dengan dokter, tim ahli gizi dan pasien atau orang tua pasien serta dokumentasi dengan menggunakan instrumen berupa pedoman wawancara, rekaman suara, kamera, alat tulis, catatan lapangan dan lainnya yang mendukung jalannya penelitian. Data yang didapat kemudian di analisa dengan menggunakan metode pengumpulan data, reduksi data, penyajian data serta verifikasi data dan pegecekan keabsahan data.

\section{Hasil Penelitian}

Hasil penelitian yang didapat adalah sebagai berikut. Berdasarkan dari hasil observasi dan informasi dilapangan, penelitian dilakukan di RSU Bhakti Rahayu Denpasar yang merupakan salah satu rumah sakit yang melayani operasi tonsilektomi, RSU Bhakti Rahayu berlokasi di Jalan Gatot Subroto II No.11, Kecamatan Denpasar Utara, Kota Denpasar Bali. Dengan dokter spesialis bedah tonsilektomi dan ahli gizi serta pasien anak anak pasca operasi tonsilitis sebagai informan kunci dalam penelitian ini.

Berdasarkan observasi dan wawancara manfaat pemberian es krim herbal sebagai makanan terhadap pasien anak-anak pasca operasi tonsilitis di RSU Bhakti Rahayu Denpasar adalah untuk memudahkan dan mengurangi rasa sakit pada saat proses menelan makanan pasca operasi. memberikan manfaat karena beberapa tanaman yang digunakan tersebut mengandung unsur tanaman obat, vitamin dan mineral sebagai penunjang nutrisi bagi pasien tonsillitis dimana adanya luka pasca bedah tonsilektomi.

Berdasarkan observasi di lapangan dalam proses pembuatan es krim herbal mengandung beberapa bahan herbal seperti daun kelor, mengkudu, rosella, dan cinnamon atau kayu manis. Komposisi dalam 1 liter es krim herbal ini adalah air 1 liter, mengkudu 250 gram, rosella kering 25 gram, kayu manis 10 gram, kelor kering 10 gram, bahan lain 350 gram. Dalam pembuatan es krim herbal ini terdiri dari beberpa tahapan, yaitu; pemilihan bahan, perebusan bahan, pengadukan bahan dan pencampuran, pendinginan, dan pengemasan. Tata cara pemanfaatan atau pemberian es krim herbal terhadap pasien anak-anak pasca operasi tonsillitis adalah dengan aturan 3 x 1 cup dalam satu hari. Pemberian dalam dosis ini dilakukan bersamaan pada saat jam makan sehingga dapat dijadikan sebagai makanan pengganti selain makanan pokok lainya.

Implikasi pemberian es krim herbal bagi 16 penderita pasca operasi tonsilitis yang di wawancarai adalah untuk meredakan rasa sakit saat menelan atau minum serta meredakan rasa perih pada luka bekas operasi.

\section{Pembahasan}

Penelitian ini menggunakan teknik pengambilan sampel dengan metode purposive sampling. Dari informan kunci, penelitian dikembangkan pada pasien anak-anak pasca operasi tonsilitis di RSU Bhakti Rahayu Denpasar. Informan ahli gizi yang didapat adalah orang yang bekerja sebagai ahli gizi di RSU Bahakti Rahayu. Informan pasien anak-anak yang didapat adalah anak yang berumur sekitar 5-15 tahun yang menjalani operasi tonsilitis atau tonsilektomi. Informasi yang terkumpul dari 
informan kunci didapat 1 (satu) orang dokter spesialis THT, 2 (dua) orang ahli gizi dan 16 (enam belas) orang pasien anak-anak pasca operasi tonsilitis.

Berdasarkan analisis data manfaat pemberian es krim herbal sebagai makanan terhadap pasien anak-anak pasca operasi tonsilitis dari informan tim ahli gizi dan pasien yang menjalani operasi tonsillitis diperoleh data sebagai berikut;

\section{Menambah nutrisi}

Hasil penelitian dari mengkonsumsi es krim herbal memberikan manfaat karena beberapa tanaman yang digunakan tersebut mengandung unsur tanaman obat, vitamin dan mineral sebagai penunjang nutrisi bagi pasien tonsillitis dimana adanya luka pasca bedah tonsilektomi. Kandungan gizi seperti susu mengandung unsur mineral, daun kelor mengandung unsur vitamin $\mathrm{C}$, kayu manis mengandung minyak atsiri yang mempunyai daya bunuh terhadap mikroorganisme, kayu manis mengandung unsur yang dapat menghentikan pendarahan dan mempunyai efek yang menenangkan. Berdasarkan hasil uji laboratorium yang dilakuakan terhadap kandungan gizi pada es krim herbal per 100 gram nya mengandung vitamin $\mathrm{C}$, protein, karbohidrat dan lemak yang disajikan dalam tabel 1 .

\section{Tabel 1. Hasil Uji Laboratrium}

\begin{tabular}{|l|l|c|c|c|}
\hline $\begin{array}{c}\text { N } \\
\mathbf{0}\end{array}$ & Parameter & Metode & Satuan & Hasil \\
\hline 1. & Vitamin C & Titrimetri & $\%$ & 0,009 \\
\hline 2. & Protein & Khjedal & $\%$ & 1,37 \\
\hline 3. & Karbohidrat & $\begin{array}{c}\text { Spektrofot } \\
\text { ometri }\end{array}$ & $\%$ & 31,84 \\
\hline 4. & Lemak & $\begin{array}{c}\text { Spektrofot } \\
\text { ometri }\end{array}$ & $\%$ & 28,35 \\
\hline
\end{tabular}

2. Mempermudah dan mengurangi rasa sakit saat mengkosumsi makanan pasca operasi

Berdasarkan analisis data observasi dan wawancara didapatkan bahwa es krim herbal merupakan pilihan makanan yang dipakai oleh pihak RSU Bhakti Rahayu dalam mengatasi keluhan pasien semasa pasca operasi tonsillitis atau tonsilektomi dan sebagai upaya untuk mempercepat pemulihan daya tahan tubuh pasien. Karena es krim herbal dipandang mempermudah makan atau minum pasien mengingat masih terdapatnya bekas luka pasca operasi.
Berdasarkan analisis data tentang tata cara pengolahan dan pemanfaatan pemberian es krim herbal pada pasien pasca operasi tonsilitis dalam penelitian ini didapatkan bahwa tata cara pengolahan es krim herbal adalah terdiri dari beberpa tahapan, yaitu: Pemilihan bahan, Perebusan bahan, Pengadukan bahan dan pencampuran, Pendinginan, Pengemasan.

Dalam proses pembuatan es krim herbal berikut ini rincian alat dan bahan yang digunakan untuk membuat es krim herbal yang terdiri dari:

\section{Panci}

Panci dalam proses pembuatan es krim herbal digunakan untuk tempat memanaskan bahan es krim herbal.

\section{Lesung}

Lesung dalam pembuatan es krim herbal digunakan sebagai alat untuk menumbuk buah mengkudu menjadi halus.

\section{Timbangan}

Timbangan dalam pembuatan es krim herbal digunakan sebagai alat untuk menakar berat bahan dasar pembuatan es krim herbal

\section{Mixer}

Mixer atau mesin pengaduk dalm pembuatan es krim herbal digunakan untuk menggaduk adonan es krim herbal

5. Saringan

Saringan dalam pembuatan es krim herbal digunakan untuk menyaring bahan dasar es krim herbal yang direbus.

\section{Gelas Ukur}

Gelas ukur dalam pembuatan es krim hrbal digunakan sebagai alat untuk menakar volume air.

\section{Talenan}

Talenan dalam pembuatan es krim herbal digunakan sebagai alat untuk alas memotong bahan dasar es krim herbal.

8. Pisau

Pisau dalam pembuatan es krim herbal digunakan sebagai alat untuk memotong bahan dasar es krim herbal.

\section{Cup plastik}

Cup plastik dalam pembuatan es krim herbal digunakan sebagai wadah atau kemasan es krim herbal.

10. Spatula

Spatula atau sendok nasi dalam pembuatan es krim herbal digunakan sebagai alat untuk mengaduk serta menciduk adonan es krim herbal.

11. Kain

Kain dalam pembuatan es krim herbal digunakan sebagai alat untuk membersihkan kotoran yang tercecer saat proses pembuatan es krim herbal. 
12. Apron atau celemek

Apron atau celemek dalam pembuatan es krim herbal digunakan sebagai alat pelindung diri dari noda dan percikan air panas.

\section{Nurse cap}

Nurse cap atau penutup kepala dalam pembuatan es krim herbal digunakan sebagai pelindung bagian kepala, agar rambut tidak jatuh dalam makanan, serta tidak meneteskan keringat. 14. Masker

Masker dalam pembuatan es krim herbal digunakan sebagai melindungi wajah dari bau yang tidak sedap serta menghindari dari paparan virus dan bakteri.

Adapun yang bahan-bahan yang digunakan dalam pembuatan es krim herbal adalah sebagai berikut:

a. Air 1 liter

b. Tepung maizena 50 gram

c. Susu bubuk 300 gram

d. Gula tebu 250 gram

e. Daun kelor 10 gram

f. Mengkudu 250 gram

g. Rosella 25 gram

h. Cinnamon atau kayu manis 10 gram

Tata cara pembuatan es krim herbal adalah sebagai berikut;

1. pemilihan bahan, Bahan yang sudah di pilih, kemudian di cuci bersih (kecuali gula tebu dan susu pengemulsi).

2. Bahan yang di cuci kemudian di rebus dan di tambahkan gula tebu (bahan dimasukan setalah air mendidih).

3. Bahan yang sudah di rebus kemudian air nya disaring.

4. Setelah perebusan bahan selanjutnya didinginkan kemudian dimasukan ke dalam mesin pengaduk dan ditambahkan tepung maizena serta susu sebagai pengemulsi

5. Jika adonan sudah mengental kemudian adonan siap dimasukan ke dalam cup dan dimasukan ke mesin pendingin.

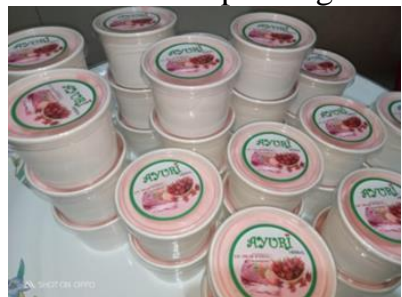

\section{Gambar 1. Produk es krim herbal}

Berdasarkan analisis data pemanfaatan pemberian es krim herbal pada pasien pasca operasi tonsilitis dalam penelitian ini didapatkan bahwa tata cara pemanfaatan atau pemberian es krim herbal terhadap pasien anak-anak pasca operasi tonsillitis adalah dengan aturan 3 x 1 cup dalam satu hari. Pemberian dalam dosis ini dilakukan bersamaan pada saat jam makan sehingga dapat dijadikan sebagai makanan pengganti selain makanan pokok lainya.

Berdasarkan analisis data didapatkan bahwa beberapa implikasi pemberian es krim herbal bagi penderita pasca operasi tonsilitis antara lain: mengurangi keluhan nyeri pada pangkal tenggorokan, mual, rasa perih, dan mempermudah proses makan dan minum pasien pasca operasi tonsilitis. Selain itu es krim herbal juga membuat daya tahan tubuh anak semakin baik karena kandungan vitamin dan mineral yang ada pada bahan herbal cukup banyak.

\section{Simpulan dan Saran}

\section{Simpulan}

Berdasarkan hasil penelitian dan pembahasan tentang manfaat es krim herbal terhadap pasien anak-anak pasca operasi tonsilitis di RSU Bhakti Rahayu Denpasar, maka bisa disimpulkan sebagai berikut:

1.

Pemberian es krim

herbal sebagai makanan terhadap pasien anak-anak pasca operasi tonsillitis di RSU Bhakti Rahayu Denpasar karena es krim herbal mampu menambah nutrisi dan mempercepat penyembuhan karena beberapa tanaman yang digunakan tersebut mengandung unsur tanaman obat, vitamin dan mineral, setiap herbal per 100 gram nya mengandung vitamin $\mathrm{C}$ sebesar 0,009\%, protein sebesar $1,37 \%$, Karbohidrat sebesar $31,84 \%$ dan gula sebesar $28,35 \%$.

2. Tata cara pengolahan es krim herbal meliputi penghitungan adonan, persiapan adonan, pencampuran, pasteurisasi, homogenisasi, pembekuan, dan pengemasan. 1 cup atau per 100 gram es krim herbal mengandung kalori sebanyak $388 \mathrm{kkal}$

3.

Implikasi es krim herbal bagi penderita pasca operasi tonsilitis yaitu: mengurangi keluhan nyeri pada pangkal tenggorokan, mual, rasa perih, dan mempermudah proses makan dan minum pasien pasca operasi tonsilitis serta menambah nutrisi dan mempercepat pembekuan darah di area luka bekas pasca operasi tonsillitis sehingga mengurangi pendarahan.

\section{Saran}

Berdasarkan hasil penelitian dan pembahasan tentang manfaat es krim herbal terhadap pasien anak-anak pasca operasi 
tonsilitis di RSU Bhakti Rahayu Denpasar, maka bisa disarankan sebagai berikut:

1. Mengingat efektivitas es krim herbal dalam mengurangi keluhan rasa sakit pasca operasi tonsilitis untuk lebih lanjut penting diadakan penelitian yang lebih spesifik terhadap produk dan nutrisi yang terkandung di dalam es krim herbal dan dilakukan uji laboratorium yang lebih mendalam. Makanan atau minuman yang sudah memiliki sertifikat pengujian, lebih disukai oleh konsumen secara luas. Oleh sebab itu, diperlukan pengujian skala laboratorium agar benar-benar teruji khasiat bahan herbal yang terdapat pada es krim.

2. Selain pemberian es krim herbal pada pasien pasca operasi tonsilitis secara rutin dan teratur, untuk pasien juga penting diperhatikan tri upastamba (tiga konsep sehat) yaitu ahara: asupan makanan dan minuman yang masuk ke dalam tubuh, wihara: aktifitas atau kegiatan yang dilakukan serta nidra: istirahat yang cukup.

\section{DAFTAR PUSTAKA}

Arbuckle, W.S. 1986. Ice Cream. Westport: The AVI Publishing Company.

Astawan, M dan Andreas L. K. 2008. Khasiat Warna-Warni Makanan. Jakarta : Gramedia. 2010. Teknologi Pengolahan Pangan dan Gizi. IPB : Bogor.

Farokah, Suprihati, Suyitno, S. 2007, HubuganTonsilitis kronik dengan prestasi belajar pada siswa kelas II Sekolah Dasar di kota Semarang. Cermin Dunia Kedokteran; 155:87- 91.

Hadiwiyoto. 1994. Pengujian Mutu Susu Dan Hasil Olahannya. Yogyakarta: Liberty.

Marshal, R. T, and S. Arbuckle. 1996. Ice Cream. 5th ed. Champhan And Hall Publishing: New York.

Nala, Ngurah. 2001. Ayurweda Ilmu Kedokteran Hindu 1. Denpasar: Upada sastra. . 2001. Ayurweda Ilmu Kedokteran Hindu 2. Denpasar: Upada sastra.

Ramadhan F, Sahrudin, Ibrahim K. 2017.analisis Faktor Resiko Kejadian Tonsilitis kronis Pada Anak Usia 5-11 Tahun di Wilayah Kerja Puskesmas Puwatu Kota Kendaari Tahun 2017. JIMKESMAS. 2(6):1-8.

Soepardi, E.A. dkk. 2007. Buku Ajar Kesehatan Telinga Hidung Tenggorok Kepala Dan Leher, Edisi 6. Jakarta : FKUI.

Widayanti, Nila, Dkk. 2018. Inovasi Pemanfaatan Sayuran Menjadi
Smoothie Dan Ice Cream Sayur. Jurnal Abadimas Adi Buana Vol. 02. No. 1.

Winarno, F. G. 1993. Pangan Gizi, Teknologi dan Konsumen. Gramedia Pustaka Utama. Jakarta.

Wiryanatha, Ida Bagus. 2019. Sehat Dalam Ayurweda. Prodi Kesehatan Ayurweda, Fak. Kesehatan Universitas Hindu Indonesia. Dalam E-Jurnal Widya Kesehatan, Volume 1, Nomor: 1. 
